\title{
Matgorzata Postuszna
}

Uniwersytet Medyczny im. K. Marcinkowskiego

w Poznaniu

\section{Problematyka ochrony zdrowia ludności wiejskiej w okresie międzywojennym na lamach "Zdrowia" i „Zdrowia Publicznego"}

„Zdrowie” - „Zdrowie Publiczne” było w okresie II Rzeczypospolitej czasopismem, na łamach którego podejmowano zagadnienia ochrony zdrowia ludności wiejskiej. Celem owej publicystyki była poprawa stanu zdrowia i ochrona zdrowia ludności wiejskiej w ramach istniejących stosunków społeczno-politycznych.

To zainteresowanie się autorów czasopisma problematyką ochrony zdrowia mieszkańców wsi, choć z różnym nasileniem, wynikało nie tylko z założeń programowych redakcji i Warszawskiego Towarzystwa Higienicznego, a następnie Polskiego Towarzystwa Higienicznego, ale w znacznej mierze z osobistego zaangażowania się $\mathrm{w}$ badania dotyczące medycyny wiejskiej dwóch kolejnych jego redaktorów naczelnych dr. Józefa Polaka i dr Marcina Kacprzaka - wybitnych polskich higienistów. Szczególnie ten ostatni bardzo interesował się sprawami wsi. Był m. in. autorem monografii Wieś płocka, inicjował wystawy i konkursy higieniczne, a także konsultował postępy wzorcowej wsi Lisków k. Kalisza ${ }^{1}$. Warto podkreślić, że właśnie Marcin Kacprzak, broszurą Zdrowie $w$ chacie wiejskiej zapoczątkował „nowy styl oświaty zdrowotnej”².

${ }^{1}$ Była to wieś, w której wprowadzono eksperyment, uznawany za prekursorski przykład realizacji założeń promocji zdrowia, a także wzór w upowszechnianiu higieny i kultury zdrowotnej. Jego inicjatorem był ks. Wacław Bliziński, proboszcz parafii Lisków. Dzięki jego pracy, wieś, zacofana cywilizacyjnie, której mieszkańcy żyli w złych warunkach higienicznych, nękani byli chorobami zakaźnymi i alkoholizmem, stała się miejscem „,dobrze funkcjonujących instytucji gospodarczych, finansowych, oświatowych [...], w której realizowano równolegle cele oświatowe, kulturalne, ekonomiczne, higieniczno-zdrowotne oraz etyczno-religijne". W. Piątkowski, Lisków społeczność lokalna promujaca zdrowie, [w:] Zdrowie i choroba. Promocja zdrowia dla gmin i instytucji edukacyjnych, red. M. Latoszek, Gdańsk 1999, s. 80. Z udziałem społeczności we wsi kolejno powstawały: dom ludowy, remiza, kanalizacja i wodociagi, łaźnia, izba porodowa, szpital (na 30 łóżek), ośrodek zdrowia, szkoła elementarna, sierociniec itd. We wsi urządzono też dwie wystawy krajowe: „Wieś polska” (1925 r.) i „Praca i kultura wsi” (1937 r., we współpracy z Polskim Towarzystwem Higienicznym i z udziałem prezydenta Ignacego Mościckiego oraz premiera Sławoja Składkowskiego).

${ }^{2}$ M. Demel, Z dziejów promocji zdrowia w Polsce, t. I-II, Studia i Monografie, nr 13, Kraków 2000, s. 150. 
Czasopismo „Zdrowie” założone zostało przez dr. med. Józefa Polaka, który był pierwszym redaktorem pisma. Pierwszy numer ukazał się w październiku 1885 r. w Warszawie. Jego założyciel, redaktor i propagator w swoim dzienniku pisał: „Pragnę wydawać pismo to $\mathrm{w}$ celu podniesienia poziomu zdrowotności i zmniejszenia odsetka śmiertelności”3. W miesięczniku „Zdrowie” J. Polak pisał, że „najważniejszym stanem jednostek i społeczeństw jest zachowanie zdrowia”. Podkreślał również, że oświata w sprawach zdrowia jest „potężną dźwignią społeczną" i zwracał uwagę na fakt, że lepiej jest dać każdemu możność zachowania zdrowia niż świadczyć pomoc finansową.

Zgodnie z deklaracją programową, czasopismo rozszerzało swoją problematykę o zagadnienia ochrony zdrowia ludności wiejskiej. W okresie międzywojennym problematyka ta omawiana była $\mathrm{w}$ różnorodnych artykułach ukazujących się w czasopiśmie. Podzielono je na dwie kategorie: pierwszą stanowiły artykuły, które w tytule sygnalizowały wieś, jako przedmiot analizy bez względu na stopień ich merytorycznego powiązania $\mathrm{z}$ zagadnieniami higieniczno-zdrowotnymi wsi, np. budownictwo wiejskie czy wychowanie fizyczne młodzieży wiejskiej. Drugą natomiast stanowiły publikacje poruszające ogólne zagadnienia medyczne, np. umieralność niemowląt bądź innej populacji, ale w odpowiednim kontekście. Zwykle w celach porównawczych pojawiały się też zagadnienia z dziedziny ochrony zdrowia ludności wiejskiej. Artykuły publikowane $\mathrm{w}$ czasopiśmie zawierały prace $\mathrm{w}$ całości poświęcone ochronie zdrowia na wsi, jak i prace, w których były tylko wzmianki na ten temat.

Stopień nasycenia czasopisma omawianą problematyką i jej struktura stanowiły też przejaw ogólniejszych tendencji i procesów występujących w polityce społecznej prowadzonej wobec wsi oraz w działalności odpowiednich organizacji i stronnictw chłopskich. Trzeba podkreślić również, że problematyka ochrony zdrowia ludności wiejskiej pojawiała się w „Zdrowiu” i w „Zdrowiu Publicznym" w wyniku przełomowych wydarzeń w dziejach czasopisma, takich jak zmiany składu osobowego redakcji, jak i zmiany tytułu czasopisma. Z początkiem 1934 r. „Zdrowie” przekształciło się w „Zdrowie Publiczne” które pozostało organem Polskiego Towarzystwa Higienicznego i głównym czasopismem higieniczno-społecznym w Polsce.

Wzrost liczby artykułów omawiających problematykę ochrony zdrowia ludności wiejskiej wynikał także z objęcia redakcji naczelnej w 1928 r. przez Marcina Kacprzaka. Silna więź Kacprzaka z wsią i problematyką zdrowotną znalazła wyraźny oddźwięk w tym miesięczniku, gdzie ochronie zdrowia ludności wiejskiej poświęcano istotną uwagę.

Te ważne dla dziejów czasopisma wydarzenia spowodowały, że międzywojenna problematyka ochrony zdrowia ludności wiejskiej z okresu międzywojnia

${ }^{3}$ Cyt. za: M. Demel, Geneza i rozwój miesięcznika „Zdrowie” $w$ dobie niewoli narodowej (1885-1918), „Zdrowie Publiczne” [dalej - ZP] 1965, nr 10, s. 437. 
została podzielona na dwa etapy: pierwszy, piętnastoletni - „Zdrowia” i drugi, pięcioletni - „Zdrowia Publicznego”. Ochrona zdrowia mieszkańców wsi w „Zdrowiu” omawiana była w znacznie mniejszym stopniu niż w „Zdrowiu Publicznym”. Jak podaje S. Kosiński, w „Zdrowiu” naliczono 127 publikacji, w tym 13 okazjonalnie sygnalizujących analizowaną przeze mnie problematykę, podczas gdy w drugim tytule wyszukano już 299 artykułów o takiej tematyce, $\mathrm{z}$ tego 61 sygnalizujących te zagadnienia ${ }^{4}$. Poza tym artykuły publikowane w „Zdrowiu Publicznym” o wiele częściej niż w „Zdrowiu” zawierały wyniki badań socjometrycznych i statystycznych, w tym nie tylko regionalnych, ale i ogólnopolskich.

Jak wspomniałam wcześniej, zagadnienia higieniczno-zdrowotne wsi w pierwszym etapie okresu międzywojennego, czyli w ostatnim okresie ukazywania się czasopisma, nie były wiodącym tematem. W tym czasie $\mathrm{w}$ prawie połowie roczników nie zamieszczono ani jednego artykułu z tego zakresu. Fakt ten świadczy o małym zainteresowaniu zespołu redakcyjno-autorskiego „Zdrowia" problematyką ochrony zdrowia ludności wiejskiej. Najkorzystniejszym dla „Zdrowia” okresem był rok 1930, kiedy ukazało się 9 artykułów z analizowanej problematyki. Kwestie ochrony zdrowia mieszkańców wsi rozpatrywali J. Danielski, J. Lubczyński, W. Łabęcki, K. Orzechowski, H. Rudziński, N. Sadowska, B. Salak, A. Szniolis czy C. Wroczyński.

Do najczęściej poruszanych w „Zdrowiu” tematów z dziedziny ochrony zdrowia ludności wiejskiej należały: stan sanitarno-higieniczny wsi i zapadalność na choroby zakaźne, problem opieki ginekologiczno-położniczej na wsi oraz zwalczanie chorób społecznych i funkcjonowanie ośrodków zdrowia.

W chwili odzyskania niepodległości stan zdrowotny społeczeństwa polskiego, szczególnie najuboższej ludności wiejskiej, był zły. Wpływały na to warunki materialne, niekorzystna sytuacja mieszkaniowa i niski poziom kultury sanitarno-higienicznej mieszkańców wsi. Powodowało to, że wieś, szczególnie wschodnie rejony Polski, była siedliskiem chorób zakaźnych, które niemal w całym okresie międzywojennym przybierały postać epidemii. Szerzenie się chorób zakaźnych stawało się klęską społeczną wymagającą zespolenia wysiłków do walki z nimi całego społeczeństwa: władz państwowych, samorządów, wojska, szkół, ugrupowań zawodowych i politycznych, inteligencji pracującej.

Szeroko dyskutowany w piśmiennictwie lekarskim Drugiej Rzeczypospolitej stan sanitarny i higieniczny wsi polskiej wywoływał zrozumiałe zainteresowanie w „Zdrowiu”. Na łamach czasopisma lansowano tezę, że najskuteczniejszym sposobem zwalczania chorób zakaźnych jest wzrost standardu higienicz-

\footnotetext{
${ }^{4}$ S. Kosiński, Problematyka ochrony zdrowia ludności wiejskiej $w$ „Zdrowiu” $i$ w „Zdrowiu Publicznym”, ZP, 1985, nr 1, s. 253.
} 
no-sanitarnego polskiej wsi. Główne artykuły O. Anzelma ${ }^{5}$, B. Ostromęckiego ${ }^{6}$ i H. Rudzińskiego ${ }^{7}$ dotyczyły przede wszystkim wpływu niekorzystnych warunków materialnych, złej sytuacji mieszkaniowej i niskiego poziomu kultury sanitarno-higienicznej na występowanie chorób zakaźnych.

Istotne znaczenie $\mathrm{w}$ sprawowaniu opieki nad ludnością wiejską miały poważne niedociagnięcia $\mathrm{w}$ polityce zdrowotnej państwa polskiego oraz braki dostatecznej liczby wykwalifikowanego personelu. W szczególny sposób dotyczyło to środowiska wiejskiego, w którym sprawowanie opieki zdrowotnej było wyjątkowo trudne. Niski poziom oświaty oraz słaba znajomość higieny i możliwości leczenia powodowały, że ludność wiejska nie odczuwała wręcz potrzeby zasięgania pomocy lekarskiej. Poza tym brak stałych wykwalifikowanych pracowników medycznych osiadłych na wsi powodował, że ludność owa pozbawiona fachowej możliwości leczenia, w czasie choroby raczej korzystała z pomocy i porad znachorów i tzw. babek aniżeli lekarza, felczera czy akuszerki.

Wiele do życzenia pozostawiał niski poziom opieki ginekologiczno-położniczej na wsi, gdyż akuszerki nie miały możliwości podnoszenia swoich kwalifikacji poprzez doszkalanie się. Poza tym brak kadr położnych i słabe ich przygotowanie fachowe powodowały, że na terenie wsi wielki odsetek porodów odbierały osoby nieuprawnione do tego, tzw. babki. Te kwestie wnikliwie rozpatrywali na łamach „Zdrowia” F. Cieszyński ${ }^{8}$, W. Labęcki ${ }^{9}$, J. Danielski ${ }^{10}$ i Z. Kołosowski ${ }^{11}$. Autorzy podkreślali doniosłą rolę położnej wiejskiej, będącej jednocześnie również higienistką. Wskazywali na fakt, że ta reprezentantka medycyny zawodowej, bezpośrednio i najczęściej kontaktuje się nie tylko z położnicą i jej rodziną, ale i z szerszymi kręgami społeczności wiejskiej. Zdaniem autorów zatem, położna-higienistka powinna być zatrudniona w każdej wsi, gdyż ma możliwość wielokierunkowego oddziaływania na postawy i kulturę zdrowotną ludności wiejskiej.

Wydawałoby się więc, że opieka zdrowotna ludności wiejskiej powinna należeć do najpilniejszych zadań służby zdrowia. Tymczasem podstawową instytucję zdrowia stanowili lekarze wolno praktykujący, których usługi były

${ }^{5}$ O. Anzelm, Kilka uwag $w$ sprawie najprostszych sposobów walki z chorobami nagminnymi, „Zdrowie” [dalej-Z] 1932, nr 5-6, s. 221.

${ }^{6}$ B. Ostromęcki, Trzy lata wzmożonej akcji porzqdkowo-sanitarnej na terenie województwa kieleckiego, Z, 1930, nr 11, s. 517-530.

${ }^{7}$ H. Rudziński, Zagadnienia sanitarne Samorzqdów na wsi w województwie wileńskim, Z, 1930, nr 1, s. 79-83.

${ }^{8}$ F. Cieszyński, W sprawie organizacji i opieki higienicznej i położniczej na wsiach Rzeczypospolitej Polskiej, Z, 1929, nr 12, s. 789-794.

${ }^{9}$ W. Labęcki, Od ,, babki wiejskiej” do położnej-higienistki, Z, 1930, nr 9-10, s. 455-473.

${ }^{10} \mathrm{~J}$. Danielski, W sprawie ochrony macierzyństwa i organizacji pomocy położniczej, Z, 1932, nr 19-20, s. 868-878.

${ }^{11}$ Z. Kołosowski, Opłakany stan położnictwa na wsi kresowej, Z, 1933, nr 1-2, s. 68-70. 
z reguły niedostępne dla ubogich mieszkańców wsi. Barierę stanowiła też niska stopa dochodów ludności wiejskiej w stosunku do wysokich honorariów lekarskich.

Z przedstawionej sytuacji władze państwowe zdawały sobie sprawę i zaczęły podejmować działania, zmierzające do poprawienia opisanego stanu rzeczy. Działania te jednak, wskutek ograniczonych możliwości gospodarczych państwa i niewłaściwej polityki społecznej wobec wsi, nie przynosiły widocznego postępu w odniesieniu do znakomitej większości polskiego społeczeństwa. Poza tym szerzenie się chorób zakaźnych i społecznych spowodowało konieczność stworzenia pewnych instytucji, które „służyłyby jako ośrodki pracy zapobiegawczej o charakterze społecznym" ${ }^{2}$. Skorzystano tu z doświadczeń i wzorów amerykańskich i zachodnioeuropejskich, przenosząc je do Polski.

Istotną rolę w przeobrażeniach systemu ochrony zdrowia odegrały ośrodki zdrowia. Były to instytucje samorządowe, oparte na amerykańskim wzorze, których celem była profilaktyka i walka $\mathrm{z}$ chorobami społecznymi. W tym celu stosowano rozmaite środki, przede wszystkim rozpoznanie i wywiad środowiskowy. Poza tym do zadań ośrodka zdrowia należało szkolenie personelu, organizowanie wzorowej służby zdrowia na terenie objętym działalnością ośrodka, polepszenie środowiska pod względem higienicznym i propagowanie oświaty sanitarnej. Pierwszy małomiasteczkowo-wiejski ośrodek zdrowia powstał w powiecie skierniewickim i finansowany był przez Fundację Rockefellera. Jednak z powodu trudnej sytuacji samorządów, wzrost liczby ośrodków zdrowia postępował bardzo powoli. W skład tekiego ośrodka wchodziły: sekcja administracyjno-sanitarna, sekcja epidemiologiczna, przychodnia dla kobiet ciężarnych, matek i dzieci, przychodnia higieniczno-szkolna z lekarzem higienistą szkolnym, przychodnia przeciwgruźlicza, przeciwjaglicza, przeciwweneryczna oraz (w zależności od potrzeb) przychodnie: przeciwalkoholowa, laryngologiczna bądź dentystyczna. Wiejskie ośrodki zdrowia z konieczności działały w innych warunkach. Brakowało zwykle odpowiedniego lokalu. Lekarz najczęściej dojeżdżał, a specjalista bardzo rzadko się tam zjawiał. Bezpośrednią pomocą lekarza w ośrodku była pielęgniarka społeczna, zwana też higienistką wywiadowczynią.

Na łamach „Zdrowia” podkreślano znaczenie odpowiedniego przygotowania do pracy w środowisku wiejskim pielegnniarki społecznej. C. Wroczyński twierdził, że podstawą jej wykształcenia jest posiadanie wiedzy dotyczącej przebiegu chorób, zapobiegania im i pielęgnowania chorego. Niekorzystna sytuacja epidemiologiczna panująca na wsi wymusza bowiem, jak podkreślał autor, specyficzne zadania pielęgniarki społecznej tam pracującej. Jej obowiązki nie mogą się ograniczać tylko do przekazania wiedzy, ale mają polegać też na zademonstrowaniu określonych czynności (np. wykonanie kąpieli dziecka,

\footnotetext{
${ }^{12}$ M. Kacprzak (red.), Ośrodki zdrowia w Polsce, Warszawa 1928, s. 17.
} 
płukanie gardła czy przygotowanie pokoju do odbycia porodu, umieszczenie w ciasnym mieszkaniu [jednoizbowym] chorego na gruźlicę i małego dziecka, $\mathrm{z}$ uwzględnieniem zasad reżimu sanitarnego lub także ścielenie łóżka $\mathrm{z}$,siennikiem" ze słomą). Często musi się ona dostosowywać do trudnych warunków, dokonując praktycznej oceny istniejących możliwości. Do tych działań niezbędna jest wiedza i doświadczenie ${ }^{13}$.

Do obowiązków pielęgniarki należało asystowanie lekarzowi w ośrodku, prowadzenie kartoteki, przygotowywanie odwiedzających do przyjęcia przez lekarza, obecność przy ewentualnych zabiegach i wysłuchiwanie udzielanych przez lekarza wskazań. Poza tym higienistka wywiadowczyni zobowiązana była odwiedzać chorych w celu wyszukiwania osób potrzebujących opieki ośrodka, przeprowadzenia wywiadu społecznego w domu chorego, pouczania go o sposobie wykonywania zleceń lekarza ośrodka zdrowia, sprawdzenia czy te zalecenia są należycie wykonane, zaprowadzenia higieny w mieszkaniu i w obejściu oraz szerzenia zasad higieny ${ }^{14}$. Podkreślić należy, że działalność ośrodka na wsi wpływała na podniesienie świadomości społecznej jej mieszkańców, uczyła elementarnych zasad higieny osobistej i otoczenia, wyrabiała nawyk korzystania $\mathrm{z}$ porady lekarskiej, zwłaszcza $\mathrm{w}$ początkowym stadium choroby, a zatem przyczyniała się do podniesienia zdrowotności wsi. Strukturą i funkcjonowaniem ośrodków zdrowia interesowali się na łamach „Zdrowia” lekarze i higieniści. Artykuły poruszające tę tematykę publikowali w czasopiśmie J. Danielski ${ }^{15}$, K. Orzechowski ${ }^{16}$, A. Wierciński ${ }^{17}$ i N. Sadowska ${ }^{18}$.

Problematyka ochrony zdrowia ludności wiejskiej w ostatnim okresie ukazywania się „Zdrowia” pojawiała się również w artykułach traktujących o warunkach zdrowotnych wsi. Autorzy tych prac rozpatrywali w nich kwestie wiejskiego budownictwa mieszkaniowego ${ }^{19}$ i wzorów konsumpcji żywności $\mathrm{w}$ środowisku wiejskim ${ }^{20}$. Były to zagadnienia niezwykle ważne dla zdrowia, a $\mathrm{w}$ omawianym środowisku, z uwagi na niski poziom kultury ogólnej i sanitarno-higienicznej, zaniedbane. Trzeba podkreślić, że w warunkach wiejskich szczególne znaczenie dla zdrowia mieszkańców wsi miało nadmierne zagęszczenie izb mieszkalnych. W jednej izbie zamieszkiwało zazwyczaj po kilka

${ }^{13}$ C. Wroczyński, Szkolenie pielęgniarek, Z, 1930, nr 10, s. 2-4.

${ }^{14}$ E. Więckowska, Cele i zadania ośrodków zdrowia w Rzeczypospolitej Polskiej $w$ latach 1925-1939, ZP, 1982, nr 7-8, s. 330-335.

${ }^{15}$ J. Danielski, Charakter i zadania „Ośrodków Zdrowia”, Z, 1930, nr 11, s. 497-506.

${ }^{16}$ K. Orzechowski, Działalność Ośrodków Zdrowia i Opieki Społecznej w powiecie warszawskim. Rok 1929, Z, 1930, nr 7-8, s. 316-322.

${ }^{17}$ A. Wierciński, Ośrodki zdrowia na Wileńszczyźnie, Z, 1933, nr 5-6, s. 228.

${ }^{18}$ N. Sadowska, Praca Ośrodka Zdrowia na wsi, Z, 1930, nr 21, s. 1017-1025.

${ }^{19}$ J. Holnicki, Budujemy na należycie odwodnionych terenach, Z, 1933, nr 19-20, s. $685-688$.

${ }^{20}$ B. Szewczykówna, Żywienie się ludu wiejskiego w Małopolsce Zachodniej, Z, 1930, nr 9-10, s. 474-485. 
osób, a niejednokrotnie całe, liczne rodziny. Poza tym mieszkania wiejskie nie mieściły się $w$ żadnych normach. Budownictwo było na ogół prymitywne i w przeważającej mierze drewniane. Domy były najczęściej niskie, wilgotne, z małymi oknami i w dodatku połączone ścianą z budynkami gospodarczymi. Ten stan rzeczy wpływał ujemnie na stan zdrowia ludności wiejskiej i na występowanie licznych chorób zakaźnych. Stosunkowo liczne występowanie chorób, szczególnie gruźlicy, na wsi było też skutkiem złego odżywiania. Jak podkreślali autorzy artykułów, wyżywienie było często skąpe i monotonne. W pożywieniu przeważała konsumpcja ziemniaków, twardej jarzyny (grochu, fasoli), kaszy czy potraw mącznych. Mięso i produkty mięsne spożywano rzadko, jedynie z okazji świąt i uroczystości rodzinnych. Jak wskazywano, jakościowe i ilościowe braki pożywienia, przy wyczerpującej pracy fizycznej, narażały ludność wiejską, a przede wszystkim dzieci i młodzież, na utratę zdrowia, a nawet życia.

Wielowątkowość poruszanej na łamach „Zdrowia” w ostatnich kilkunastu latach wydawania problematyki ochrony zdrowia mieszkańców wsi sprawiła, że czasopismo to stało się cennym źródłem dla badaczy dziejów medycyny i upowszechniania wiedzy o warunkach higieniczno-zdrowotnych ludności wiejskiej.

Drugi etap międzywojennej problematyki ochrony zdrowia mieszkańców wsi, opisany już w „Zdrowiu Publicznym”, obejmuje lata 1934-1939. W tym okresie, ukazujące się pod zmienionym tytułem i przy nowym składzie redakcyjnym, na czele z Marcinem Kacprzakiem, czasopismo zawierało znacznie bogatsze treści $\mathrm{w}$ aspekcie analizowanych zagadnień niż w omówionym wcześniej czasie.

W pierwszym pięcioleciu „Zdrowia Publicznego” można wyróżnić następujące grupy tematyczne artykułów poruszających ogólne i organizacyjne zagadnienia wiejskiej służby zdrowia, wiejską spółdzielczość zdrowia, zwalczanie chorób zakaźnych, takich jak gruźlica, dur brzuszny i plamisty oraz inne choroby zakaźne, rolę pielęgniarki społecznej i położnej w przemianach warunków zdrowotnych wsi.

Poważne niedociagnnięcia w opiece zdrowotnej państwa polskiego, szczególnie w odniesieniu do wsi, wpływały niekorzystnie na zdrowie i życie obywateli. Niepokojącym zjawiskiem były braki wykwalifikowanego personelu. W szczególny sposób dotyczyło to środowiska wiejskiego, w którym sprawowanie opieki zdrowotnej było wyjątkowo trudne. Wobec małej liczby lekarzy w tym środowisku, gdzie 1 lekarz przypadał przeciętnie na 9624 mieszkańców (podczas gdy według norm międzynarodowej konferencji higieny wsi z roku 1931 powinno pracować dla ludności wiejskiej 13272 lekarzy, było ich tylko 2758), i bardzo niskiego poziomu opieki lekarskiej nad ludnością wiejską należało się przede wszystkim ograniczyć do pomocy w nagłych wypadkach, opieki nad matką i dzieckiem, walki z chorobami zakaźnymi i chorobami społecznymi oraz opieki nad umysłowo chorymi. Na wsi brakowało również 
położnych i pielęgniarek społecznych. Kwestię zapewnienia wsi odpowiedniej liczby lekarzy i personelu pomocniczego wnikliwie rozpatrywali J. Danielski ${ }^{21}$ i M. Kacprzak ${ }^{22}$.

Ochrona zdrowia ludności wiejskiej wymagała odpowiedniego przygotowania lekarzy do pracy w środowisku wiejskim. Jak podkreślano w „Zdrowiu Publicznym", lekarz pracujący na wsi powinien znać specyfikę działania w tym środowisku, uwzględniać trudności komunikacyjne i konieczność częstego przemieszczania się do chorych na różne odległości, brać pod uwagę prymitywne środki lokomocji oraz brak wielu udogodnień. Dlatego celowe było osiedlanie tu lekarzy młodych. Lekarz pracujący na prowincji powinien spełniać następujące warunki: posiadać ogólną znajomość medycyny, charakteryzować się sprężystością, znajomością higieny oraz mieć odpowienie przygotowanie społeczne. Na ten temat pisali głównie W. Odrzywolski ${ }^{23}$ i W. Skomoroch ${ }^{24}$.

Szczególną rolę w pracy na wsi i w przemianach warunków zdrowotnych ludności wiejskiej odgrywała pielęgniarka społeczna i położna. W tej kwestii wypowiadano się na łamach „Zdrowia Publicznego" wyjątkowo obszernie. Swoje publikacje poświęcone wyłącznie tym zawodom medycznym prezentowali M. Kacprzak ${ }^{25}$ i H. Makowska ${ }^{26}$.

Ważną rolę odegrały $\mathrm{w}$ środowisku wiejskim kasy chorych, powstałe na bazie ustawodawstwa ubezpieczeniowego. Obok ubezpieczeń od wypadków, inwalidztwa i na starość, najważniejsze było ubezpieczenie na wypadek choroby. Ustawa o obowiązkowym ubezpieczeniu w tym zakresie ukazała się w 1920 r., tworząc jednolity system organizacyjny, opierający się na państwowych kasach chorych. Ustawowo działalność ich obejmować miała tę część mieszkańców wsi, która utrzymywała się z pracy najemnej. Byli to w zasadzie robotnicy rolni i ich rodziny, którzy, z uwagi na charakter pracy, warunki bytowania, poziom kultury ogólnej i sanitarno-higienicznej, stanowili wyraźnie zarysowaną grupę społeczna. Ubezpieczenie zapewniało pracownikom najemnym i ich rodzinom bezpłatną pomoc leczniczą, zasiłki na wypadek choroby, śmierci, połogu. Ustawodawstwo społeczne w zakresie ubezpieczeń na wypadek choroby nie było jednak jednolite w całej Polsce, w poszczególnych jej częściach istniały dość znaczne różnice w świadczeniach leczniczych. Ustawa ubezpieczeniowa nie obejmowała wszystkich warstw społeczeństwa. Poza jej zasięgiem pozostawały grupy ludności pracującej samodzielnie, o niskich dochodach, a więc przede wszystkim chłopi, najliczniejsza warstwa społeczna. Olbrzymia większość ludności wiejskiej, niezatrudniona na podstawie stosunku roboczego lub

\footnotetext{
${ }^{21}$ J. Danielski, Pomoc lecznicza na wsi, ZP, 1939, nr 2, s. 15-36.

${ }^{22}$ M. Kacprzak, Medycyna zapobiegawcza na wsi, ZP, 1939, nr 2, s. 84-104.

${ }^{23}$ W. Odrzywolski, Przygotowanie lekarzy do pracy na wsi, ZP, 1939, nr 2, s. 37-40.

${ }^{24}$ W. Skomoroch, Z zagadnień lecznictwa na Polesiu, ZP, 1939, nr 5, s. 431-442.

${ }^{25}$ M. Kacprzak, Pielęgniarka społeczna na wsi, ZP, 1937, nr 1, s. 45.

${ }^{26}$ H. Makowska, Pielegniarka wiejska, ZP, 1939, nr 1, s. 41-46.
} 
służbowego, co stanowiło podstawę do ubezpieczeń społecznych i ochrony pracy, nie podlegała opiece zdrowotnej. Do pomocy lekarskiej dla ludności wiejskiej zobowiązane były samorządy gmin wiejskich, ale - niestety - przeznaczały one stosunkowo niewielkie nakłady na opiekę zdrowotną. Propagatorami samodzielnego rozwiązywania kwestii zdrowotnych na wsi, przez tworzenie wiejskich spółdzielni zdrowia, byli działacze ruchu ludowego, jak np. Ignacy Solarz. Kwestię wprowadzenia na wsi ubezpieczeń społecznych i działalności Kas Chorych omawiali na łamach „Zdrowia Publicznego” J. Babecki ${ }^{27}$ i W. Likowski $^{28}$. Dodać należy, że stopniowe rozszerzanie w okresie międzywojennym zasięgu oddziaływań lecznictwa ubezpieczeniowego animowało środowisko lekarskie, rodząc liczne konflikty i spory. Ścierały się tu poglądy zmierzające do przywrócenia wolnej praktyki lekarskiej i likwidacji Kas Chorych, z opiniami części środowiska lekarskiego, skupionej wokół M. Kacprzaka, żądającymi pełnego uspołecznienia tego zawodu.

Duże nadzieje w zakresie ochrony zdrowia ludności wiejskiej i modyfikacji postaw zdrowotnych mieszkańców wsi wiązano $\mathrm{z}$ wiejskimi spółdzielniami zdrowia. Placówki te zakładane były dzięki zabiegom i pomocy finansowej miejscowych spółdzielni rolniczych, częściowej dotacji samorządu gminnego i powiatowego oraz Ubezpieczalni Społecznej. Spółdzielczość zdrowia przybliżała ludności wiejskiej instytucje medyczne w sensie przestrzennym i finansowym. Uprzedzenia i negatywne postawy wobec zawodów i instytucji medycznych wynikały $\mathrm{z}$ wysokich opłat za porady lekarskie i leczenie szpitalne. Spółdzielnie zdrowia gwarantowały natomiast bezpłatną profilaktykę i o $50 \%$ tańsze, w stosunku do prywatnych opłat, leczenie. Członkowie spółdzielni płacili połowę taksy, a nie-członkowie pełną taksę. Pierwsza wiejska spółdzielnia zdrowia powstała w 1935 r. we wsi Markowa koło Przeworska, a założona została z inicjatywy działacza ruchu ludowego, inżyniera Ignacego Solarza. W środowisku lekarskim natomiast prekursorem tej formy pomocy lekarskiej był dr Franciszek Cieszyński. Spółdzielnia zdrowia składała się z obszernego ambulatorium, apteki, kapieliska (łaźni) i mieszkań dla personelu medycznego. W wiejskiej spółdzielni zdrowia zatrudnieni byli lekarz, higienistka, położna oraz dorywczo lekarz dentysta. Problematykę wiejskiej spółdzielczości zdrowia zainaugurował na łamach „Zdrowia Publicznego” F. Cieszyński ${ }^{29}$, a następnie kontynuowali ją W. Ciekot ${ }^{30}$ i K. Wyszomirski ${ }^{31}$.

${ }^{27} \mathrm{~J}$. Babecki, Możliwości rozciagnięcia ubezpieczenia społecznego na wypadek choroby na wsi, ZP, 1939, nr 2, s. 67-68.

${ }^{28}$ W. Likowski, Gminne Kasy Chorych, ZP, 1937, nr 4, s. 324-330; tenże, Nadzór nad pomoca leczniczq dla pracowników rolnych $w$ województwach poznańskiem i pomorskiem - lekarz powiatowy, ZP, 1936, nr 5, s. 492-501.

${ }^{29}$ F. Cieszyński, Opieka nad zdrowiem wsi a spółdzielczość, ZP, 1934, nr 4, s. 292.

${ }^{30}$ W. Ciekot, Spótdzielnie zdrowia, ZP, 1938, nr 8, s. 816-817.

${ }^{31}$ K. Wyszomirski, Spółdzielnia zdrowia w walce o zdrowie wsi, ZP, 1939, nr 2, s. 76-78. 
Szerzące się na wsi choroby zakaźne stawały się z każdym rokiem coraz bardziej groźne dla środowiska wiejskiego. Były to choroby o charakterze społecznym, gdyż czyniły poszczególne jednostki nieproduktywnymi, rzutowały bezpośrednio na warunki bytowe ich najbliższego otoczenia, w konsekwencji doprowadzając do ruiny gospodarstwa. Najgroźniejsza była gruźlica, szerząca się w zastraszającym tempie w rodzinach wiejskich. Niezwykle groźnymi chorobami w środowisku wiejskim były także dur brzuszny i plamisty, jaglica, występująca w największym odsetku u młodzieży szkół powszechnych, poza tym czerwonka, płonica, błonica, odra. Przyczyną tego stanu rzeczy były, co podkreślali autorzy artykułów w „Zdrowiu Publicznym”, złe warunki materialne, niehigieniczny tryb życia i wyczerpanie fizyczne z powodu nadmiernej, nieracjonalnej pracy. Zjawisko to wiązało się również $\mathrm{z}$ niedostatecznym przeprowadzeniem ustawodawstwa sanitarnego, spowodowanym często brakiem środków lokomocji dla stosownych organów, którym powierzyło się zwalczanie chorób zakaźnych. Stan „zagruźliczenia” najuboższych warstw społecznych na wsi był wysoki. Większość chorujących na tę chorobę stanowiły dzieci i ludzie młodzi. Świadczą o tym sprawozdania z działalności lekarskiej wojskowych komisji poborowych, stwierdzające znaczny odsetek zaawansowanej gruźlicy u mężczyzn w tym wieku. Artykuły dotyczące omawianego tematu podejmowało liczne grono autorów, a wśród nich najaktywniejsi byli: K. Lachowicz ${ }^{32}$, W. Leśniewski ${ }^{33}$, W. Labęcki ${ }^{34}$, J. Narolewski ${ }^{35}$, L. Rostkowski ${ }^{36}$, M. Skokowska-Rudolf $^{37}$, M. Kołaczyńska ${ }^{38}$ i F. Zimmermann ${ }^{39}$.

$\mathrm{W}$ okresie międzywojennym, z uwagi na złe warunki materialne, brak jakiejkolwiek oświaty sanitarno-higienicznej i wynikającej stąd nieświadomości w zakresie spraw zdrowia i choroby, ludność wiejska często nie odczuwała wręcz potrzeby zasięgania pomocy lekarskiej. Poza tym w ówczesnych warunkach społeczno-politycznych nie uważano bynajmniej zachowania lub podnoszenia swego stanu zdrowia za największą wartość życia. Główną rolę odgrywały tu przede wszystkim czynniki ekonomiczne.

${ }^{32} \mathrm{~K}$. Lachowicz, Ostre choroby zakaźne $w$ województwie stanistawowskim $w$ latach 1932-1937 (Próba opisu epidemicznego terenu), ZP, 1939, nr 3, s. 125-141.

${ }^{33}$ W. Leśniewski, Walka z gruźlica na wsi, ZP, 1939, nr 2, s. 129-137.

${ }^{34}$ W. Labęcki, Zwalczanie duru brzusznego na wsi, ZP, 1939, nr 2, s. 114-115.

${ }^{35}$ J. Narolewski, Zapobieganie i zwalczanie chorób społecznych na terenach wsi kresowej, ZP, 1939, nr 2, s. 164-171.

${ }^{36}$ L. Rostkowski, Jaglica w Polsce jako zagadnienie higieny wsi, ZP, 1939, nr 2, s. 173-179.

${ }^{37}$ M. Skokowska-Rudolf, Zagruźliczenie wsi polskiej, ZP, 1939, nr 2, s. 151-163.

${ }^{38}$ M. Kołaczyńska, Walka z gruźlica na wsi (Przodownice zdrowia), ZP, 1939, nr 2, s. $138-143$.

${ }^{39}$ F. Zimmermann, Rozmieszczenie duru plamistego na terenie powiatu przemyślańskiego w latach od 1923 do 1938, ZP, 1939, nr 1, s. 60-65. 
Na łamach „Zdrowia Publicznego” podkreślano istotną rolę personelu medycznego w zakresie przebudowy świadomości zdrowotnej ludności wiejskiej poprzez nauczanie mieszkańców wsi poprawnych wzorców higienicznych we własnych domach. Zdawano sobie bowiem sprawę, że w walce o zdrowie ludności, szczególnie mieszkańców wsi, istotny akcent położyć należy na higieniczne wychowanie. Kwestie te rozpatrywał na łamach „Zdrowia Publicznego" nade wszystkim L. Nehrlich ${ }^{40}$.

Głównym „hamulcem” rozwoju wiejskiej służby zdrowia były poważne ograniczenia i bariery finansowe, ale nie tylko one warunkowały tę sytuację. Ważną kwestią stały się tu również ustalenia modelowe i strukturalne. W latach trzydziestych środowisko lekarskie zaktywizowało się w zakresie opracowywania różnych modeli i projektów terenowej służby zdrowia. W sprawie organizacji opieki lekarskiej na wsi najbardziej aktywnie wypowiadał się w czasopiśmie K. Niedźwiałowski ${ }^{41}$.

$\mathrm{Z}$ przedstawionych powyżej zagadnień, składających się na problematykę ochrony zdrowia ludności wiejskiej, wynika, że w międzywojennym okresie dziejów czasopisma przywiązywano do niej coraz większą wagę. Zagadnienia ochrony zdrowia ludności wiejskiej znacznie częściej omawiano w ,Zdrowiu Publicznym" niż wcześniej poruszano w artykułach publikowanych w „Zdrowiu”. Prace dotyczące wsi, omawiające problemy zapewnienia jej mieszkańcom dostępnej i sprawnie funkcjonującej opieki medycznej - lekarskiej, pieleggniarskiej i położniczej, wzbudzały stopniowo coraz większe zainteresowanie powiększającego się grona badaczy i organizatorów ochrony zdrowia mieszkańców wsi.

Proces modyfikacji postaw zdrowotnych oraz świadomości społecznej zachodził na wsi bardzo powoli i wymagał dłuższego czasu. Poprawa w dziedzinie uświadamiania higienicznego, pielęgnacji zdrowia, nabywania właściwych nawyków i obyczajów zdrowotnych postępowała w ślad za podnoszeniem się poziomu oświaty i kultury oraz zamożności, zależała od przekształceń społeczno-zawodowych i dostępności służby zdrowia na wsi.

Analizując podejmowaną przez autorów „Zdrowia”, a później „Zdrowia Publiczego", problematykę ochrony zdrowia ludności wiejskiej w II Rzeczypospolitej należy stwierdzić, że czasopismo to jako jedno $\mathrm{z}$ nielicznych w tym okresie całkowicie wiernie ukazywało przemiany zarówno pozytywne, jak i negatywne, jakie dokonywały się w dziedzinie opieki zdrowotnej nad mieszkańcami wsi, walki $\mathrm{z}$ chorobami zakaźnymi i społecznymi w tym środowisku oraz w lecznictwie ubezpieczeniowym, a także w spółdzielniach zdrowia. Ta wiarygodność relacji decyduje o tym, że pisma stanowią dla współczesnych badań nad wiejską służbą zdrowia cenne i wyjątkowo interesujące źródła historyczno-medyczne.

${ }^{40}$ L. Nehrlich, Drogi uzdrowotnienia wsi wolyńskiej, ZP, 1936, nr 5, s. 475-482.

${ }^{41}$ K. Niedźwiałowski, $W$ sprawie organizacji opieki lekarskiej na wsi, ZP, 1937, nr 6, s. $515-519$. 